\title{
The Solidarity in the Spanish Funding of the Autonomous Communities
}

\author{
Sabrina Bellanca ${ }^{1}$, Marc Martínez Sans ${ }^{1} \&$ Julien Vandernoot ${ }^{1}$ \\ ${ }^{1}$ Warocqué School of Business and Economics, University of Mons (UMONS), Belgium \\ Correspondence: Julien Vandernoot, Warocqué School of Business and Economics, University of Mons \\ (UMONS), 17, Place Warocqué, 7000 Mons, Belgium. E-mail: Julien.Vandernoot@umons.ac.be
}

Received: March 4, 2013

Accepted: March 22, 2013

Online Published: April 17, 2013

doi:10.5539/ibr.v6n5p45

URL: http://dx.doi.org/10.5539/ibr.v6n5p45

\begin{abstract}
In this paper, we analyze the Spanish funding of the Autonomous communities, which has been modified in 2009. Therefore, we study the Spanish mechanism of tax retrocession and the system of funds whose purpose is to finance some needs of the Spanish autonomous communities. We also study the impact of the process of funding on the wealth of the communities. It enables us to conclude that there is not only a reduction of the gap between the autonomous communities but also a paradox of revenues in some cases.
\end{abstract}

Keywords: Spanish autonomous communities, funding, federalism, paradox of revenue, tax

\section{Introduction}

The topic of funding in Spain is not frequently discussed in scientific literature. Nevertheless the former Spanish system of funding has been evoked by Bosch \& Duràn (2008) and Ruiz-Huerta Carbonell \& Herrero Alcade (2008). Lago-Penas \& Madies (2005) and Petithomme (2009) provide for their part a critical analysis of the fiscal federalism in Spain. The current system of funding has been analyzed by Blochliger, Hansjörg and Camila Vanmalle (2012). In 2009, the new Spanish system of funding came into force. This system is complex and is not the same for all the autonomous communities.

Most autonomous communities belong to the common regime but another regime, the foral regime is also used in some cases. In this article, we will focus on the common regime but will not consider Canary Islands which belong to this regime but with some changes. We will first analyze the Spanish mechanism of tax retrocession to the autonomous communities. A part of the tax collected in each autonomous community is returned to the autonomous community concerned, the rest goes to the State. The tax concerned by this retrocession are the value added tax, the personal income tax, the tax on alcoholic products, the tax on intermediate goods, the tax on beer, the tax on manufactured snuff, the tax on oil and the tax on electricity. Then, we will focus on the funds whose purpose is to finance some needs of the autonomous communities. The funds which are currently used are: the resources to reinforce the welfare state, the additional resources, the competitivity fund, the third additional disposition, the fund for cooperation, the basic public services guarantee fund, the total adequacy fund and the inter-territorial compensation fund. This will enable us to see how the Spanish system of funding influences the wealth of the communities and to see whether or not a paradox of revenue or an equalizing effect is present. We will therefore compare the money that the autonomous communities get after the process of funding and what they would get without this process.

\section{Method}

On the basis of the information found on the website of the Ministry of Finance and Public Administration, we first calculate the money collected for each tax by the government in each autonomous community. Then we calculate the money kept by the by the Spanish government and the money transferred to the autonomous communities and this, for each tax. After that, we show the repartition of the funds between the autonomous communities. Finally, by dividing the money collected in each autonomous community by the population in 2009 , before and after the process of funding, we show how the money collected per capita varies in each autonomous community. 


\section{Spanish Federal Model: Mechanisms of Tax Retrocession and Funding}

\subsection{Retrocession of Taxes}

\subsubsection{IVA (Value Added Tax)}

$50 \%$ of the revenue from this tax is transferred tothe Spanish autonomous communities. The tax reached 33.567 billion euros in 2009 .

\subsubsection{IRPF (Personal Income Tax)}

A part of this tax is transferred to the Spanish autonomous communities. Each community has the right to modify its rate of taxation. In 2009, the IRPF reached 60.009 billion euros of which 34.530 billion euros where transferred to the Spanish communities.

\subsubsection{Tax on Alcohol and Alcoholic Products}

$58 \%$ of the revenue from this tax is transferred to the Spanish communities. This revenue reached 762.389 million euros in 2009 of which442.186 million euros were transferred to the Spanish autonomous communities.

\subsubsection{Tax on Intermediate Goods}

The Spanish communities receive 58\% of the revenue from this tax. In 2009, they received 10.093 million euros.

\subsubsection{Tax on Beer}

$58 \%$ of the revenue from this tax is transferred to the Spanish communities. This revenue reached 259.811 million euros in 2009 of which 150.690 million euros were transferred to the Spanish communities.

\subsubsection{Tax on Manufactured Snuff}

The Spanish communities get 58\% of the revenue from this tax. The transfer reached 4.136 billion euros in 2009 .

\subsubsection{Tax on Oil}

$58 \%$ of the revenue from this tax is transferred to the Spanish communities. This revenue reached 9.851 billion euros in 2009 of which 5.714 billion euros were transferred to the Spanish communities.

\subsubsection{Tax on Electricity}

The Spanish communities receive the whole revenue from this tax. In 2009, they received1.219 billion euros.

The repartition of these taxes is shown in tables 1,2 and 3.

Table 1 . Money collected by the Spanish government in each autonomous community (thousands $€$, 2009)

\begin{tabular}{|c|c|c|c|c|c|c|c|c|c|}
\hline Autonomous community & IVA & IRPF & $\begin{array}{l}\text { Tax on Alcohol } \\
\text { and Alcoholic } \\
\text { Products }\end{array}$ & $\begin{array}{l}\text { Tax on } \\
\text { Intermediate } \\
\text { Goods }\end{array}$ & $\begin{array}{l}\text { Tax on } \\
\text { Beer }\end{array}$ & $\begin{array}{l}\text { Tax on } \\
\text { Manufacture } \\
\text { d Snuff }\end{array}$ & Tax on Oil & $\begin{array}{l}\text { Tax on } \\
\text { Electricity }\end{array}$ & TOTAL \\
\hline Catalonia & 6496357.76 & 13619375.46 & 156264.08 & 3492.72 & 48704.28 & 1446076.42 & 1730979.71 & 249499.64 & 23750750.07 \\
\hline Galicia & 2079001.62 & 3180670.88 & 44858.78 & 1260.34 & 13828.44 & 394520.08 & 724492.96 & 103370.64 & 6542003.74 \\
\hline Andalusia & 5854761.16 & 7761147.48 & 132444.35 & 2985.65 & 51312.37 & 1390673.35 & 1739595.74 & 190542.38 & 17123462.48 \\
\hline Principality of Asturias & 868313.68 & 1618748.33 & 22777.01 & 564.67 & 6984.19 & 176630.47 & 242325.33 & 53742.05 & 2990085.73 \\
\hline Cantabria & 498274.48 & 854554.50 & 15422.72 & 353.79 & 4731.23 & 100730.10 & 156522.61 & 21959.17 & 1652548.60 \\
\hline La Rioja & 255642.46 & 450483.71 & 6271.28 & 125.07 & 2206.74 & 48312.64 & 81801.42 & 8986.41 & 853829.73 \\
\hline Region of Murcia & 1004971.48 & 1419962.43 & 21995.71 & 457.28 & 7845.92 & 257432.83 & 397925.27 & 41879.16 & 3152470.08 \\
\hline Valencian Community & 3877578.54 & 5797676.66 & 92092.40 & 2003.07 & 31465.10 & 943672.48 & 1093278.92 & 141857.02 & 11979624.19 \\
\hline Aragon & 1110800.70 & 2124501.21 & 29330.68 & 622.30 & 8566.06 & 230097.40 & 413115.06 & 52124.06 & 3969157.47 \\
\hline Castile-La Mancha & 1407957.34 & 2066389.72 & 24772.72 & 564.59 & 10383.76 & 342584.04 & 650702.91 & 64802.94 & 4568158.02 \\
\hline Extremadura & 693786.00 & 907400.03 & 15963.89 & 319.05 & 5160.52 & 193303.97 & 300524.84 & 24288.76 & 2140747.06 \\
\hline Balearic Islands & 1444567.80 & 1463690.76 & 27765.94 & 590.55 & 9637.28 & 284753.64 & 287083.35 & 29678.69 & 3547768.01 \\
\hline Madrid & 5985427.32 & 15517577.74 & 121334.58 & 2831.33 & 43384.76 & 924092.45 & 1096901.73 & 162208.95 & 23853758.86 \\
\hline Castile and Leon & 1989190.06 & 3226391.71 & 51094.81 & 1230.66 & 15600.05 & 398126.73 & 936033.81 & 73954.74 & 6691622.57 \\
\hline TOTAL & 33566630.40 & 60008570.62 & 762388.95 & 17401.07 & 259810.70 & 7131006.60 & 9851283.66 & 1218894.61 & 112815986.61 \\
\hline
\end{tabular}

Source: Spanish Ministry of Finance and Public Administration and own elaboration. 
Table 2. Money transferred by the Spanish government to the autonomous communities (thousands $€$, 2009)

\begin{tabular}{|c|c|c|c|c|c|c|c|c|c|}
\hline Autonomous community & IVA & IRPF & $\begin{array}{l}\text { Tax on Alcohol } \\
\text { and Alcoholic } \\
\text { Products }\end{array}$ & $\begin{array}{l}\text { Tax on } \\
\text { Intermediate } \\
\text { Goods }\end{array}$ & $\begin{array}{l}\text { Tax on } \\
\text { Beer }\end{array}$ & $\begin{array}{l}\text { Tax on } \\
\text { Manufacture } \\
\text { d Snuff }\end{array}$ & Tax on Oil & $\begin{array}{l}\text { Tax on } \\
\text { Electricity }\end{array}$ & TOTAL \\
\hline Catalonia & 3248178.88 & 7869111.17 & 90633.16 & 2025.78 & 28248.48 & 838724.33 & 1003968.23 & 249499.64 & 13330389.67 \\
\hline Galicia & 1039500.81 & 1888093.18 & 26018.09 & 731.00 & 8020.49 & 228821.65 & 420205.92 & 103370.64 & 3714761.78 \\
\hline Andalusia & 2927380.58 & 4555928.21 & 76817.73 & 1731.67 & 29761.18 & 806590.54 & 1008965.53 & 190542.38 & 9597717.82 \\
\hline Principality of Asturias & 434156.84 & 936058.51 & 13210.67 & 327.51 & 4050.83 & 102445.67 & 140548.69 & 53742.05 & 1684540.77 \\
\hline Cantabria & 249137.24 & 497663.85 & 8945.18 & 205.20 & 2744.11 & 58423.46 & 90783.12 & 21959.17 & 929861.33 \\
\hline La Rioja & 127821.23 & 259242.25 & 3637.34 & 72.54 & 1279.91 & 28021.33 & 47444.82 & 8986.41 & 476505.83 \\
\hline Region of Murcia & 502485.74 & 830130.25 & 12757.51 & 265.22 & 4550.63 & 149311.04 & 230796.66 & 41879.16 & 1772176.21 \\
\hline Valencian Community & 1938789.27 & 3338990.17 & 53413.59 & 1161.78 & 18249.76 & 547330.04 & 634101.77 & 141857.02 & 6673893.40 \\
\hline Aragon & 555400.35 & 1224562.00 & 17011.79 & 360.93 & 4968.32 & 133456.49 & 239606.74 & 52124.06 & 2227490.68 \\
\hline Castile-La Mancha & 703978.67 & 1222688.33 & 14368.18 & 327.46 & 6022.58 & 198698.74 & 377407.69 & 64802.94 & 2588294.59 \\
\hline Extremadura & 346893.00 & 537351.24 & 9259.05 & 185.05 & 2993.10 & 112116.30 & 174304.41 & 24288.76 & 1207390.91 \\
\hline Balearic Islands & 722283.90 & 855241.37 & 16104.24 & 342.52 & 5589.62 & 165157.11 & 166508.34 & 29678.69 & 1960905.79 \\
\hline Madrid & 2992713.66 & 8617667.94 & 70374.06 & 1642.17 & 25163.16 & 535973.62 & 636203.00 & 162208.95 & 13041946.56 \\
\hline Castile and Leon & 994595.03 & 1896908.16 & 29634.99 & 713.78 & 9048.03 & 230913.51 & 542899.61 & 73954.74 & 3778667.85 \\
\hline TOTAL & 16783315.20 & 34529636.63 & 442185.58 & 10092.61 & 150690.20 & 4135983.83 & 5713744.53 & 1218894.61 & 62984543.19 \\
\hline
\end{tabular}

Source: Spanish Ministry of Finance and Public Administration and own elaboration.

Table 3. Money kept by the Spanish government (thousands $€$, 2009)

\begin{tabular}{|c|c|c|c|c|c|c|c|c|c|}
\hline Autonomous community & IVA & IRPF & $\begin{array}{l}\text { Tax on Alcohol } \\
\text { and Alcoholic } \\
\text { Products }\end{array}$ & $\begin{array}{l}\text { Tax on } \\
\text { Intermediate } \\
\text { Goods }\end{array}$ & $\begin{array}{l}\text { Tax on } \\
\text { Beer }\end{array}$ & $\begin{array}{l}\text { Tax on } \\
\text { Manufactured } \\
\text { Snuff }\end{array}$ & Tax on Oil & $\begin{array}{l}\text { Tax on } \\
\text { Electricity }\end{array}$ & TOTAL \\
\hline Catalonia & 3248178.88 & 5750264.29 & 65630.91 & 1466.94 & 20455.80 & 607352.10 & 727011.48 & 0.00 & 10420360.40 \\
\hline Galicia & 1039500.81 & 1292577.70 & 18840.69 & 529.34 & 5807.94 & 165698.44 & 304287.04 & 0.00 & 2827241.96 \\
\hline Andalusia & 2927380.58 & 3205219.27 & 55626.63 & 1253.97 & 21551.20 & 584082.81 & 730630.21 & 0.00 & 7525744.67 \\
\hline Principality of Asturias & 434156.84 & 682689.82 & 9566.35 & 237.16 & 2933.36 & 74184.80 & 101776.64 & 0.00 & 1305544.97 \\
\hline Cantabria & 249137.24 & 356890.65 & 6477.54 & 148.59 & 1987.12 & 42306.64 & 65739.50 & 0.00 & 722687.28 \\
\hline La Rioja & 127821.23 & 191241.46 & 2633.94 & 52.53 & 926.83 & 20291.31 & 34356.59 & 0.00 & 377323.89 \\
\hline Region of Murcia & 502485.74 & 589832.18 & 9238.20 & 192.06 & 3295.29 & 108121.79 & 167128.61 & 0.00 & 1380293.87 \\
\hline Valencian Community & 1938789.27 & 2458686.49 & 38678.81 & 841.29 & 13215.34 & 396342.44 & 459177.15 & 0.00 & 5305730.79 \\
\hline Aragon & 555400.35 & 899939.21 & 12318.88 & 261.36 & 3597.75 & 96640.91 & 173508.33 & 0.00 & 1741666.79 \\
\hline Castile-La Mancha & 703978.67 & 843701.39 & 10404.54 & 237.13 & 4361.18 & 143885.30 & 273295.22 & 0.00 & 1979863.43 \\
\hline Extremadura & 346893.00 & 370048.79 & 6704.83 & 134.00 & 2167.42 & 81187.67 & 126220.43 & 0.00 & 933356.14 \\
\hline Balearic Islands & 722283.90 & 608449.39 & 11661.69 & 248.03 & 4047.66 & 119596.53 & 120575.01 & 0.00 & 1586862.21 \\
\hline Madrid & 2992713.66 & 6899909.80 & 50960.52 & 1189.16 & 18221.60 & 388118.83 & 460698.73 & 0.00 & 10811812.30 \\
\hline Castile and Leon & 994595.03 & 1329483.55 & 21459.82 & 516.88 & 6552.02 & 167213.23 & 393134.20 & 0.00 & 2912954.73 \\
\hline TOTAL & 16783315.20 & 25478933.99 & 320203.35 & 7308.44 & 109120.51 & 2995022.80 & 4137539.14 & 0.00 & 49831443.43 \\
\hline
\end{tabular}

Source: Spanish Ministry of Finance and Public Administration and own elaboration.

\subsection{Funds}

\subsubsection{Resources to Reinforce the Welfare State}

A total amount of 4.598 billion euros will be distributed among the communities. $75 \%$ of this amount will be given to the Spanish communities which belong to the common regime of financing according to the relative weight of the variation of their adjusted population between 1999 and 2009. 
Table 4. Variables and weighting of the variables to calculate the adjusted population or unit of need

\begin{tabular}{ll}
\hline VARIABLES & WEIGHTING \\
\hline Population & $30 \%$ \\
Surface & $1.8 \%$ \\
Spread & $0.6 \%$ \\
Insularity & $0.6 \%$ \\
Protected population distributed & $38 \%$ \\
equivalent in seven age-groups & $8.5 \%$ \\
Population over 65 & $20.5 \%$ \\
Population between 0 to 16 & \\
\hline
\end{tabular}

Source: Spanish Ministry of Finance and Public Administration.

The balance will be divided into three parts:

$50 \%$ will be devoted to the communities according to the relative weight of their adjusted population in 2009 .

$40 \%$ will be distributed to the communities according to the relative weight of their potential dependent population in 2009.

$10 \%$ will be given to the communities according to the relative weight of dependent people entitled to benefits in 2009.

The repartition of this fund is showed in table 5 .

\subsubsection{Additional Resources}

This fund is divided into three parts.

50 million euros are distributed to communities whose population is more spread than the average. This amount will be distributed according to the number of singular entities of population of the community with respect to the number of singular entities of population of all the communitieswhich meet this condition. The spread will be measured by inhabitants per singular entity of population.

50 million euros are distributed to communities with a lower population density than the average. This amount will be distributed according to the relative weight of adjusted population of each community with a lower population density than the average with respect to the total population of communities with a lower population density than the average. The population density will be measured by inhabitant per square kilometre, referring to the values of 2009 .

236.9 million euros are distributed to the communities as funding of the Linguistic Standardization Policy.

The repartition of this fund is showed in table 5 .

\subsubsection{Autonomic Convergence Funds}

There are two autonomic convergence funds whose goal is to reduce the difference in the resources per inhabitant of the Spanish communities: the competitivity fund and the third additional disposition.

The competitivity fund is created with additional resources from the State (in 2009, 2.573 billion euros) to reinforce equity and efficiency in financing the needs of people and reduce the differences in financing per capita between the communities. At the same time it encourages autonomy and fiscal capacity. The amount of this fund is distributed between the Spanish communities whose funding per capita is below the average or below their fiscal capacity, depending on their relative adjusted population.

The repartition of additional resources is showed in table 5.

The Third additional disposition is a compensation for a community which combining a negative total adequacy fund (cf. infra) with a negative basic public services guarantee fund (cf. infra), do not reach the average level of funding for adjusted population after the implementation of the competitivity fund. In 2009 , it is only the case for Balearic Islands.

The repartition of these funds is showed in table 5 .

\subsubsection{Fund for Cooperation}

The purpose of this fund is to harmonize the development of communities by stimulating the growth of wealth and convergence of the communities in terms of rent. 1.13 billion euros will be distributed in 2009 . 
To get money from this fund, Spanish communities must satisfy at least one of the following conditions:

- The gross domestic product per capita of the community is lower than $90 \%$ of the average from the communities which belong to common regime. The GDP per capita will be measured by the average from the last three years.

- The population density of the community is lower than $50 \%$ of the average population density from the communities of common regime.

- The growth of the population of the community is lower than $90 \%$ of the average of the communities from common regime and it has a population density per square kilometre lower than $125 \%$ of the average population density of communities from common regime. The increase in the population will be measured in the last three years and the population density from the last year.

The money from the fund for cooperation is divided into two parts:

Two thirds of the fund for cooperation will be distributed between all the communities which meet at least one condition, according to their population with respect to the total population of the communities that receive money from the fund and to the distance between their GDP per capita and the average, with this formulation:

Where:

$$
P F C_{i}=P_{i} / P_{t}^{*}\left(1+\left(\left(C_{m}-C_{i}\right) / C_{m}\right)\right)
$$

$\mathrm{P}_{\mathrm{i}}$ : is the population in the community concerned.

$\mathrm{P}_{\mathrm{t}}$ : is the total population in all the communities that benefit from the fund.

$\mathrm{C}_{\mathrm{m}}$ : is the average GDP per capita in all the communities that benefit from the fund.

$\mathrm{C}_{\mathrm{i}}$ : is the average GDP per capita in each community.

One third of the money in the fund for cooperation will be distributed between the communities that have an increase in the population lower than $50 \%$ of the average of communities from common regime. It will be distributed according to the population in each community with respect to the population of all the communities that meet this condition.

The repartition of this fund is showed in table 5 .

\subsubsection{Basic Public Services Guarantee Fund}

The aim of this fund is to ensure that the Spanish communities receive enough money to provide their citizens with basic public services. The fund is financed by the communities which have to contribute to the fund with $75 \%$ of their tax capacity and by the State which gave 3.3 billion euros to the fund in 2009 . The tax capacity of the communities is the amount of money they receive when they levy some taxes. They are too numerous to be mentioned here.

Each community then gets money from the fund according to its adjusted population. We are now able to measure the net transfer from the fund to each Spanish community, which can be positive or negative, as shown in table 5 .

\subsubsection{Total Adequacy Fund}

The total adequacy fund provides each Spanish community with the difference between its global funding requirements and the sum of its tax capacity plus the money from the basic public services guarantee fund. The repartition of this fund is showed in table 5 .

\subsubsection{Inter-Territorial Compensation Fund}

This fund is distributed among the Spanish communities which were considered as receivers by the convergence objective of the European Union (those whose incomes per capita is less than $75 \%$ of the European Union average. The most important distribution criterion of this fund is the population of the communities which benefit from it but other criteria such as surface and unemployment are also taken into account.

In 2009, the fund distributed 1.23 billion euros among the beneficiaries. The repartition of this fund is showed in table 5 . 
Table 5. Repartition of funds among the Spanish autonomous communities in 2009 (thousands $€$ )

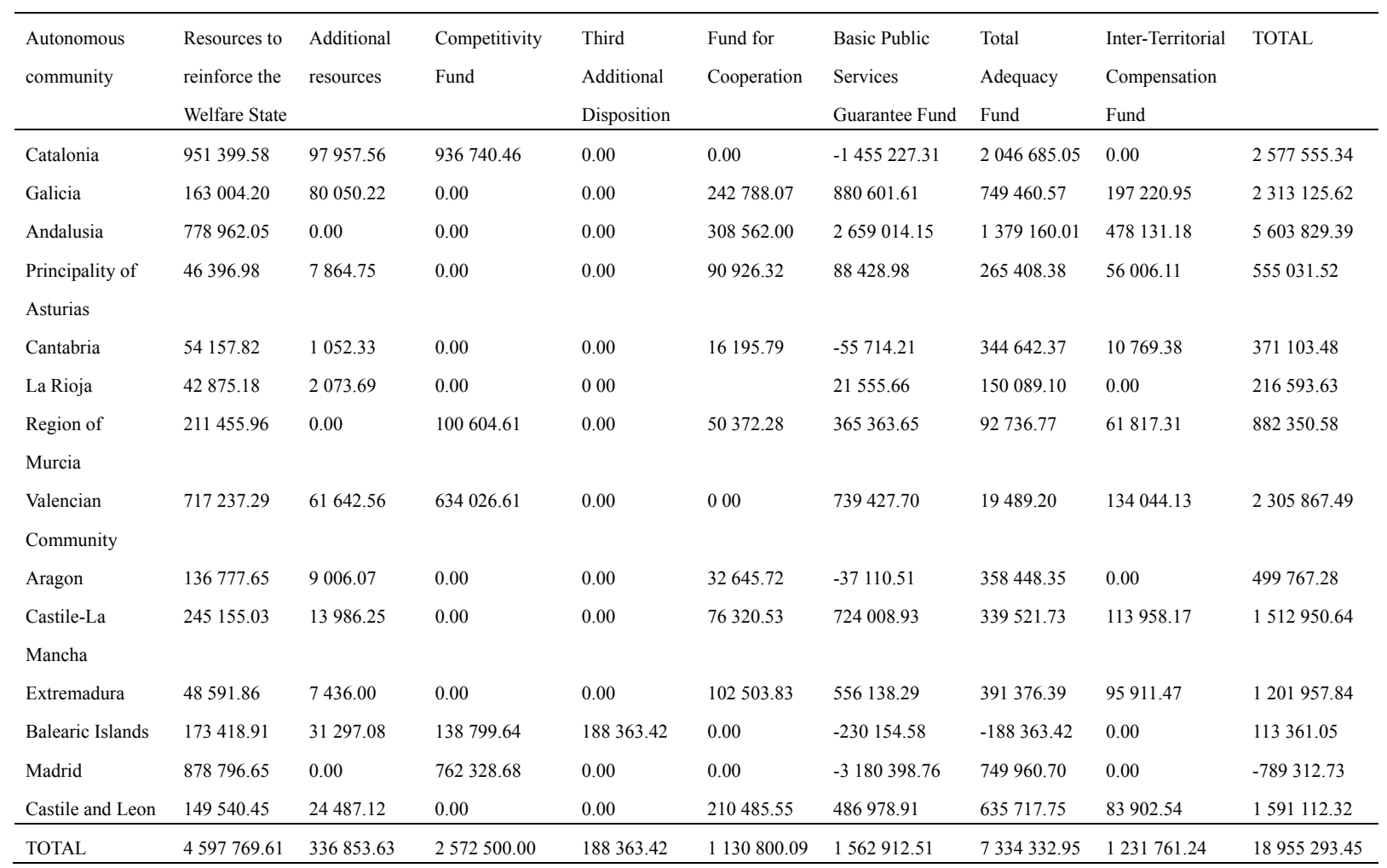

Source: Spanish Ministry of Finance and Public Administration and own elaboration.

\section{Results}

We are now able to calculate the results of the funding process for the Spanish communities. Table 6 shows how much the communities win or lose due to the funding process. Table 7 and table 8show the rating of each community with respect to the average, before and after the process of financing. Figure 1shows it graphically. Table 9 indicates the position of the communities before and after the system of funding.

Several observations can be made on the basis of these tables and picture. We can see that the four communities which collect the more tax per capita (Madrid, Balearic Islands, Catalonia and Aragon) lose money after the process of funding while the other ten earn money. We also note that the gap between the poorest and the richest community in terms of tax decreases after the process of funding. (The ratings with respect to the average range between 89.67 and 112.33 instead of between 71.75 and 138).

But we also observe that the positions of the communities change a lot after the process of financing:

Madrid moves from the $1^{\text {st }}$ position to the $10^{\text {th }}$ and the Valencian community from the $9^{\text {th }}$ position to the $14^{\text {th }}$ while Galicia moves from the $10^{\text {th }}$ position to the $3^{\text {rd }}$ and Extremadura moves from the last position to the $2^{\text {nd }}$. We can thus conclude that it exists a paradox of revenue in the Spanish system of funding and not only an equalizing effect. Indeed, after the process of funding, some communities which were initially poorer receive in total more per capita that communities which were initially richer than them. However, this could be useful to support the economy of the poorest Spanish autonomous communities. 
Table 6. Calculation of the result of the funding process for each autonomous community in 2009

\begin{tabular}{|c|c|c|c|c|c|}
\hline Autonomous community & $\begin{array}{l}\text { Money that the Central } \\
\text { Government gets from each } \\
\text { CC.AA. (thousands } € \text { ) }\end{array}$ & Rate (\%) & $\begin{array}{l}\text { Money that each community } \\
\text { puts in the process of funding } \\
\text { (thousands } € \text { ) }\end{array}$ & $\begin{array}{l}\text { Money that each community } \\
\text { receives in the process of } \\
\text { funding (thousands } € \text { ) }\end{array}$ & $\begin{array}{l}\text { Result of the } \\
\text { funding process } \\
\text { (thousands } € \text { ) }\end{array}$ \\
\hline Catalonia & 10420360.40 & 20.91121525 & 3963782.22 & 2577555.34 & -1386226.88 \\
\hline Galicia & 2827241.96 & 5.67361041 & 1075449.50 & 2313125.62 & 1237676.12 \\
\hline Andalusia & 7525744.67 & 15.10240152 & 2862704.53 & 5603829.39 & 2741124.86 \\
\hline Principality of Asturias & 1305544.97 & 2.61992204 & 496613.91 & 555031.52 & 58417.61 \\
\hline Cantabria & 722687.28 & 1.45026359 & 274901.72 & 371103.48 & 96201.76 \\
\hline La Rioja & 377323.89 & 0.75720040 & 143529.56 & 216593.63 & 73064.07 \\
\hline Region of Murcia & 1380293.87 & 2.76992552 & 525047.51 & 882350.58 & 357303.07 \\
\hline Valencian Community & 5305730.79 & 10.64735521 & 2018237.43 & 2305867.49 & 287630.06 \\
\hline Aragon & 1741666.79 & 3.49511608 & 662509.51 & 499767.28 & -162742.23 \\
\hline Castile-La Mancha & 1979863.43 & 3.97312077 & 753116.70 & 1512950.64 & 759833.94 \\
\hline Extremadura & 933356.14 & 1.87302650 & 355037.67 & 1201957.84 & 846920.17 \\
\hline Balearic Islands & 1586862.21 & 3.18445965 & 603623.67 & 113361.05 & -490262.62 \\
\hline Madrid & 10811812.30 & 21.69676725 & 4112685.90 & -789312.73 & -4901998.63 \\
\hline Castile and Leon & 2912954.73 & 5.84561580 & 1108053.63 & 1591112.32 & 483058.69 \\
\hline TOTAL & 49831443.43 & 100 & 18955293.45 & 18955293.45 & 0.00 \\
\hline
\end{tabular}

Source: Spanish Ministry of Finance and Public Administration and own elaboration.

Table 7. Calculation of the ratings of the autonomous communities with respect to the average, before the process of financing of communities (considering the tax revenue) in 2009

\begin{tabular}{|c|c|c|c|c|}
\hline Autonomous community & Money collected (thousands $€$ ) & Population in each community in 2009 & Money collected per capita $(€)$ & $\begin{array}{l}\text { Rating with respect to the } \\
\text { average }\end{array}$ \\
\hline Catalonia & 23750750.07 & 7475420 & 3177.18 & 117.40 \\
\hline Galicia & 6542003.74 & 2796089 & 2339.70 & 86.45 \\
\hline Andalusia & 17123462.48 & 8302923 & 2062.34 & 76.21 \\
\hline Principality of Asturias & 2990085.73 & 1085289 & 2755.11 & 101.80 \\
\hline Cantabria & 1652548.60 & 589235 & 2804.57 & 103.63 \\
\hline La Rioja & 853829.73 & 321702 & 2654.10 & 98.07 \\
\hline Region of Murcia & 3152470.08 & 1446520 & 2179.35 & 80.53 \\
\hline Valencian Community & 11979624.19 & 5094675 & 2351.40 & 86.89 \\
\hline Aragon & 3969157.47 & 1345473 & 2950.01 & 109.01 \\
\hline Castile-La Mancha & 4568158.02 & 2081313 & 2194.84 & 81.10 \\
\hline Extremadura & 2140747.06 & 1102410 & 1941.88 & 71.75 \\
\hline Balearic Islands & 3547768.01 & 1095426 & 3238.71 & 119.67 \\
\hline Madrid & 23853758.86 & 6386932 & 3734.78 & 138.00 \\
\hline Castile and Leon & 6691622.57 & 2563521 & 2610.32 & 96.45 \\
\hline TOTAL & 112815986.61 & 41686928 & 2706.27 & 100.00 \\
\hline
\end{tabular}

Source: Spanish Ministry of Finance and Public Administration and own elaboration. 
Table 8. Calculation of the ratings of the autonomous communities with respect to the average, after the process of financing of communities (considering the money that the communities have after the process of funding) in 2009

\begin{tabular}{|c|c|c|c|c|c|c|}
\hline Autonomous community & $\begin{array}{l}\text { Money collected from the } \\
\text { Central Government } \\
\text { (thousands } € \text { ) }\end{array}$ & $\begin{array}{l}\text { Money collected from the } \\
\text { process of funding } \\
\text { (thousands } € \text { ) }\end{array}$ & $\begin{array}{l}\text { Total money } \\
\text { collected } \\
\text { (thousands } € \text { ) }\end{array}$ & $\begin{array}{l}\text { Population in each } \\
\text { community in } \\
2009\end{array}$ & $\begin{array}{l}\text { Money } \\
\text { collected per } \\
\text { capita }(€)\end{array}$ & $\begin{array}{l}\text { Rating with } \\
\text { respect to } \\
\text { the average }\end{array}$ \\
\hline Catalonia & 13330389.67 & 2577555.34 & 15907945.01 & 7475420 & 2128.03 & 108.26 \\
\hline Galicia & 3714761.78 & 2313125.62 & 6027887.40 & 2796089 & 2155.83 & 109.68 \\
\hline Andalusia & 9597717.82 & 5603829.39 & 15201547.21 & 8302923 & 1830.87 & 93.15 \\
\hline Principality of Asturias & 1684540.77 & 555031.52 & 2239572.29 & 1085289 & 2063.57 & 104.98 \\
\hline Cantabria & 929861.33 & 371103.48 & 1300964.81 & 589235 & 2207.89 & 112.33 \\
\hline La Rioja & 476505.83 & 216593.63 & 693099.46 & 321702 & 2154.48 & 109.61 \\
\hline Region of Murcia & 1772176.21 & 882350.58 & 2654526.79 & 1446520 & 1835.11 & 93.36 \\
\hline Valencian Community & 6673893.40 & 2305867.49 & 8979760.89 & 5094675 & 1762.58 & 89.67 \\
\hline Aragon & 2227490.68 & 499767.28 & 2727257.96 & 1345473 & 2026.99 & 103.12 \\
\hline Castile-La Mancha & 2588294.59 & 1512950.64 & 4101245.23 & 2081313 & 1970.51 & 100.25 \\
\hline Extremadura & 1207390.91 & 1201957.84 & 2409348.75 & 1102410 & 2185.53 & 111.19 \\
\hline Balearic Islands & 1960905.79 & 113361.05 & 2074266.84 & 1095426 & 1893.57 & 96.34 \\
\hline Madrid & 13041946.56 & -789312.73 & 12252633.83 & 6386932 & 1918.39 & 97.60 \\
\hline Castile and Leon & 3778667.85 & 1591112.32 & 5369780.17 & 2563521 & 2094.69 & 106.57 \\
\hline TOTAL & 62984543.19 & 18955293.45 & 81939836.64 & $41686928^{*}$ & 1965.60 & 100.00 \\
\hline
\end{tabular}

Source: Spanish Ministry of Finance and Public Administration and own elaboration.

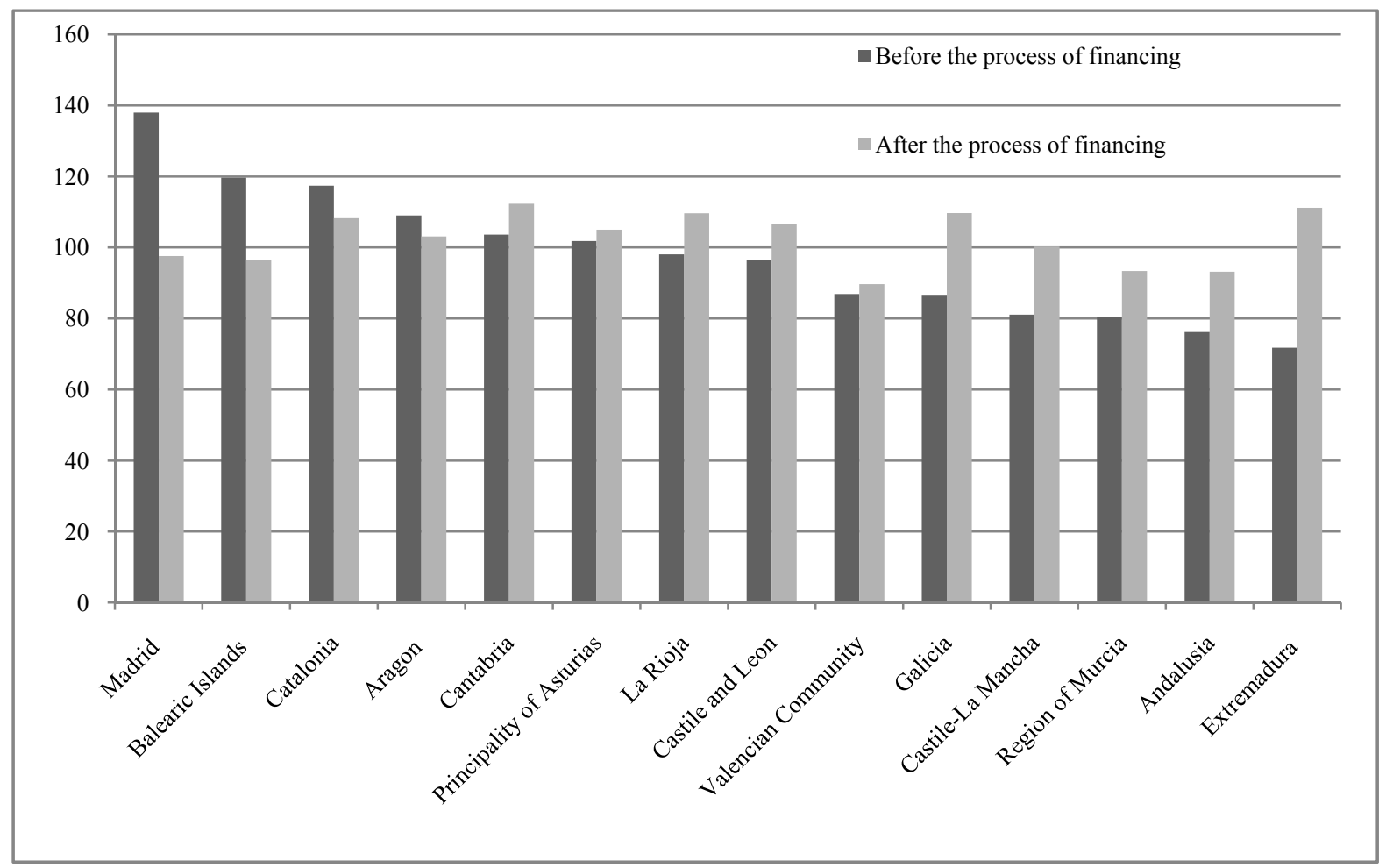

Figure 1. Comparison between the money per capita with respect to the average that each autonomous community gets before and after the process of financing in 2009 
Table 9. Positions of the autonomous communities before and after the financing system in 2009

\begin{tabular}{lllll}
\hline \multicolumn{2}{l}{ Before the system of funding } & & \multicolumn{2}{l}{ After the system of funding } \\
\cline { 1 - 2 } Position & Autonomous community & Position & Autonomous community \\
\hline 1 & Madrid & & 1 & Cantabria \\
2 & Balearic Islands & & 2 & Extremadura \\
3 & Catalonia & & 3 & Galicia \\
4 & Aragon & & 4 & La Rioja \\
5 & Cantabria & & 5 & Catalonia \\
6 & Principality of Asturias & & 6 & Castile and Leon \\
7 & La Rioja & & 7 & Principality of Asturias \\
8 & Castile and Leon & & 9 & Aragon \\
9 & Valencian Community & & 10 & Castile-La Mancha \\
10 & Galicia & & 11 & Madrid \\
11 & Castile-La Mancha & 12 & Balearic Islands \\
12 & Region of Murcia & 13 & Region of Murcia \\
13 & Andalusia & 14 & Andalusia \\
14 & Extremadura & & Valencian Community \\
\hline
\end{tabular}

\section{Conclusion}

A reform of the financing of Spanish autonomous communities occurred in 2009. It has significantly changed the economic landscape of these ones. The purpose of this reform was, on the one hand, to increase the part of resources directly collected by the communities and, on the other hand, to decrease community disparities related to resources per capita (Petithomme, 2009).

The aim of this paper was to explain the funding mechanism of the Spanish communities, introduced by the reform of 2009 and to analyze to what extent it generates solidarity between communities and influences the wealth of these ones.

After introducing the different taxes and the corresponding mechanism of tax retrocession, we analyzed the funds from which the communities benefit in order to satisfy their needs.

This analysis enabled us to know if the funding mechanism met the initial objectives, namely the increase of the solidarity and the reduction of the wealth gap between the different communities.

So, by comparing the situation of each community before and after the reform of 2009 , we first found that there is a smoothing of community revenues. Indeed, some communities loose while others win. Nevertheless, the result of the new funding mechanism goes further than just a reduction of the wealth gap; it reverses the situation of some communities. Indeed, Madrid, for instance, which was the richest community, moves to the $10^{\text {th }}$ position while Galacia moves from the 10th position to the 3rd position.

We can so conclude that there is a paradox of revenue. But this turnaround may be legitimate because it is doubtless essential to relaunch the economy in the poorest communities. This situation is not an isolated case. Indeed, in Belgium, for instance, we can observe a paradox of revenue between the three regions. The Walloon Region, which was the poorest region, became richer after the process of financing than the Flemish regions, which was the richest before the process of funding (Pagano, Vandernoot \& Tyrant, 2011).

\section{References}

Blöchliger, H., \& Vammalle, C. (2012). Spain: Reforming the funding of Autonomous Communities. Reforming Fiscal Federalism and Local Government: Beyond the Zero-Sum Game. Paris: OECD Publishing. http://dx.doi.org/10.1787/9789264119970-en

Bosch, N., \& Duran, J. (2008). Fiscal Federalism and Political Decentralization: Lessons from Spain, Germany and Canada. Cheltenham, UK.

Lago-Penas, S., \& Madiès, T. (2005). Le nouveau fédéralisme financier en Espagne. Une analyse critique. Revue de l'OFCE, 3(94), 373-396. http://dx.doi.org/10.3917/reof.094.0373

Pagano, G., Vandernoot, J., \& Tyrant, T. (2011). Vingt ans de solidarité entre les entités fédérées (1989-2009). Courrier hebdomadaire du CRISP, 2122, 1-39. http://dx.doi.org/10.3917/cris.2122.0005

Petithomme, M. (2009). L'Etat espagnol et le financement autonomique-Le dilemme de la conciliation entre autonomie régionale et solidarité national dans le contexte de fédéralisation asymétrique (1980-2009). 
Fédéralisme Régionalisme, 9(2), 1-24.

Ruiz-Huerta Carbonell, I., \& Herrero Alcalde, A. (2008). Fiscal Equalization in Spain. In Bosh, N., \& Duran, J. (Eds.), Fiscal Federalism and Political Decentralization: Lessons from Spain, Germany and Canada. Cheltenham, UK.

Spanish Ministry of Finance and Public Administration. Retrieved from http://www.minhap.gob.es/en-gb/paginas/home.aspx 